Review

\title{
Recent advances in naphtha catalytic cracking by nano ZSM-5: A review
}

\author{
Shayan Miar Alipour a,b,* \\ a Faculty of Chemical Engineering, Amirkabir University of Technology (Tehran Polytechnic), P.O. Box 15875-4413, Hafez Ave., Tehran, Iran \\ b Particles and Catalysis Research Laboratory, University of New South Wales, UNSW Sydney, NSW 2052, Australia
}

A R T I C L E I N F O

Article history:

Received 4 February 2016

Accepted 31 March 2016

Published 5 May 2016

\section{Keywords:}

Nano ZSM-5

Crystal size

Naphtha cracking

Light olefins

Reaction parameters

\section{A B S T R A C T}

This review discussed the use of nano ZSM-5 in naphtha catalytic cracking. The impact of nano ZSM-5 on product selectivity, reaction conversion and catalyst lifetime were compared with micro-sized ZSM-5. The application of nano ZSM-5 not only increased the catalyst lifetime, but also gave more stability for light olefins selectivity. The effects of the reaction parameters of temperature and feedstock on the performance of nano ZSM-5 were investigated, and showed that high temperature and linear alkanes as feedstock improved light olefin selectivity and conversion.

(C) 2016, Dalian Institute of Chemical Physics, Chinese Academy of Sciences. Published by Elsevier B.V. All rights reserved.

\section{Introduction}

Light olefins, such as ethylene and propylene, are important raw materials and the demands for them are growing. These materials are feedstock used in different industries such as the production of resins, polyethylene, polypropylene, ethylene oxide, fibers and other chemicals [1-4].

The main method for the production of light olefins has been naphtha thermal cracking. Due to high energy consumption, high reaction temperature, high amount of $\mathrm{CO}_{2}$ emission, difficult control of the selectivity of specific light olefins and also low yield of ethylene and propylene (approx. 25\% and $13 \%$, respectively), much attention has been given to developing more efficient processes [5-13]. The catalytic cracking of naphtha is a promising substitute for thermal cracking. Unlike the thermal process, catalytic cracking is more efficient in energy use and gives high yields of propylene and ethylene at relatively low temperatures [14-25].

There are two different pathways for the catalytic cracking of hydrocarbons: the monomolecular and bimolecular mechanisms. The monomolecular pathway involves the protonation of an alkane to form an intermediate pentacoordianted carbonium ion that cracks to yield an alkane and alkene. This is the main mechanism for paraffin cracking. The bimolecular pathway is a sequential process involving the protonation of a double bond to form a tricoordinated carbenium ion followed by isomerization and $\beta$-scission to form a free olefin $[15,26,27]$.

Different zeolites such as ZSM-5, zeolite A, zeolite X, zeolite Y, zeolite ZK-5, zeolite ZK-4, synthetic mordenite, dealuminatedmordenite, and naturally occurring zeolites including chabazite, faujasite, mordenite were studied for catalytic naphtha cracking $[4,5,20]$. The appropriate catalyst for naphtha cracking is an acidic zeolite such as ZSM-5 [14,15,19-34]. ZSM-5 is a synthetic zeolite with a high silica content. The framework

\footnotetext{
* Corresponding author. Tel: +61-431287016; Fax:+61-293855966; E-mail: shayan_a@aut.ac.ir, s.miaralipour@student.unsw.edu.au DOI: 10.1016/S1872-2067(15)61091-9 | http://www.sciencedirect.com/science/journal/18722067 | Chin. J. Catal., Vol. 37, No. 5, May 2016
} 
Table 1

Micropore volume and external surface area of two prepared samples [52].

\begin{tabular}{lcc}
\hline Sample & $V_{\mathrm{m}}\left(\mathrm{cm}^{3} / \mathrm{g}\right)$ & External surface area $\left(\mathrm{m}^{2} / \mathrm{g}\right)$ \\
\hline Nano ZSM-5 & 0.18 & 35.3 \\
Micro ZSM-5 & 0.18 & 5.9 \\
\hline
\end{tabular}

$V_{\mathrm{m}}$ : Micropore volume.

structure of ZSM-5 consists of one straight and one sinusoidal intersecting channels, with a 10-membered ring opening (pentasil zeolite). Due to its high thermal and hydrothermal stability, resistance to deactivation, high acidic and activity, cationexchange capability, well-ordered pore network and molecular shape selectivity arising from a unique framework structure, ZSM-5 zeolite has received a lot of attention as a catalyst, especially in catalytic cracking [35-43].

However, there are some limitations which hinder ZSM-5 in extensive use for cracking. Generally, in high acidic zeolites, such as ZSM-5, the lifetime of the zeolite decreases due to an increase in coke formation on the catalyst surface $[35,42,43]$. In (a)

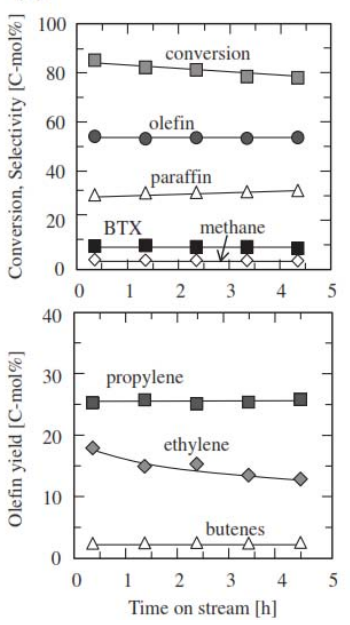

(b)

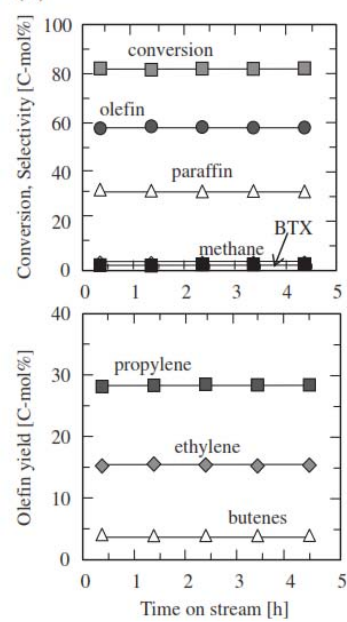

Fig. 1. Conversion, selectivity and olefin yields for $n$-hexane cracking over micro ZSM-5 (a) and nano ZSM-5 (b) [52].

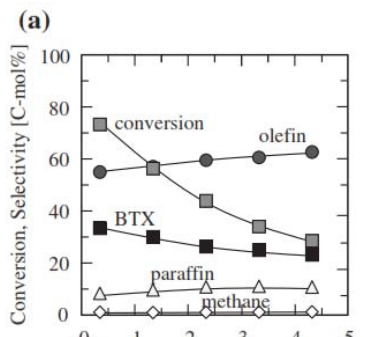

(b)
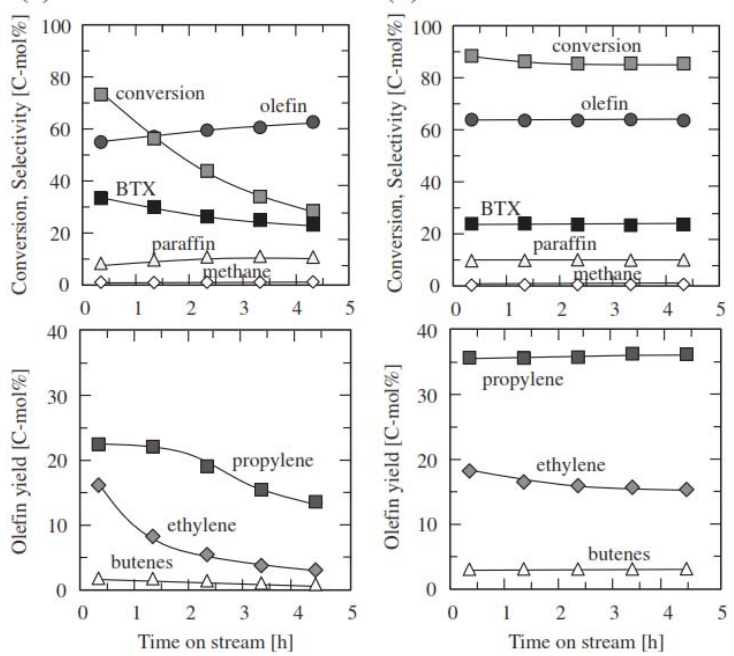

Fig. 2. Conversion, selectivity and olefin yields for cyclohexane cracking over micro ZSM-5 (a) and nano ZSM-5 (b) [52]. fact, coke fouls the catalyst surface and blocks the micropores, resulting in the deactivation of zeolite $[18,44]$. Moreover, due to large crystal size of the zeolite compare to its micropores, the diffusion and transfer of reactants and product molecules within the pores are limited [45].

One method to overcome these problems is the reduction of the zeolite crystal size to the nano scale. Decreasing of the zeolite crystal size not only provides more surface, and therefore more active sites, but also the resistance to pore diffusion will be reduced [18,35,42,43,45-51]. In fact, it is expected that by application of the nano instead of the micro ZSM-5 as catalyst, the activity and deactivation rate will be improved significantly.

This review discusses different researches on the effect of ZSM-5 crystal size reduction in the naphtha catalytic cracking process. Different factors such as selectivity and lifetime of nano ZSM-5 are compared with those of the micro-sized samples and the results are discussed thoroughly. Moreover, the effect of the reaction parameters of temperature and feedstock were investigated to clarify the most suitable reaction condition for naphtha catalytic cracking using nano ZSM-5.

\section{Nano ZSM-5 application in naphtha catalytic cracking}

\subsection{Product selectivity and olefin yield}

The reduction of the crystal size affects the selectivity and yield of the products by controlling the diffusion rate of reactants and products through the pores of the ZSM-5 catalyst. In fact, smaller catalyst particles result in the reduction of both reactants and products diffusion resistance, so the residence time in the catalyst pores becomes shorter and consequently further reactions which lead to heavier hydrocarbons and coke are inhibited.

In an experiment, Konno et al. [52] synthesized nano ZSM-5 zeolite by the emulsion method [53-58]. For comparison, micro-sized ZSM-5 was also prepared by the conventional method. The size of the nano ZSM-5 was $90 \mathrm{~nm}$ and the micro-sized sample was $2300 \mathrm{~nm}$. Table 1 gives the micropore volume and (a)
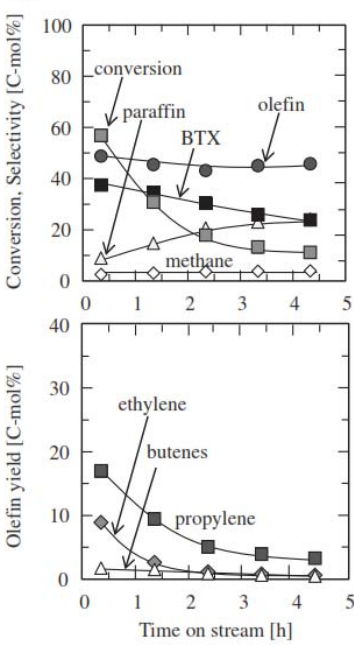

(b)
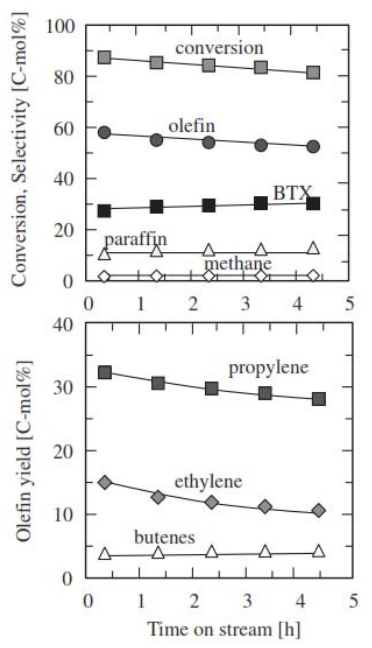

Fig. 3. Conversion, selectivity, and olefin yields for methyl-cyclohexane cracking over micro ZSM-5 (a) and nano ZSM-5 (b) [52]. 
surface area of these two samples. Although the micropore volume remained constant, the specific surface area of the nano zeolite was more than the micro-sized sample. To investigate the effect of crystal size on the selectivity and olefin yield, both of the samples were used in naphtha cracking with three different feedstocks: $n$-hexane, cyclohexane, and methyl-cyclohexane. The product selectivity and olefin yield of both samples for the three different reactants are shown in Figs. 1-3 and Table 2. As can be seen in Fig. 1, during $n$-hexane cracking, micro ZSM-5 showed a lower selectivity for olefin and relatively higher selectivity for BTX (benzene, toluene and xy- lene which is also a coke precursor) compared to nano ZSM-5. This was due to the higher diffusion resistance within the micro ZSM-5 pores which led to a longer residence time inside the catalyst and subsequently further reactions of light olefin to other hydrocarbons, such as aromatization, took place. Also the ethylene yield decreased with time for micro-sized ZSM-5, while it was stable with nano ZSM-5. The instability of the olefin yield over the micro ZSM-5 was more pronounced when cyclohexane and methyl-cyclohexane were used as feedstock. It was observed in Figs. 2 and 3 that a considerable reduction in ethylene and propylene yields occurred versus reaction time-

Table 2

Product selectivity, olefin yield and conversion in different investigations.

\begin{tabular}{|c|c|c|c|c|c|c|c|c|}
\hline \multirow{2}{*}{$\begin{array}{l}\text { Sample crystal } \\
\text { size }(\mathrm{nm})\end{array}$} & \multirow{2}{*}{$\begin{array}{l}\text { Reaction time } \\
\text { (h) }\end{array}$} & \multirow{2}{*}{ Feedstock } & \multirow{2}{*}{ Conversion (\%) } & \multicolumn{2}{|c|}{ Product selectivity (\%) } & \multicolumn{2}{|c|}{ Olefin yield (\%) } & \multirow{2}{*}{ Ref. } \\
\hline & & & & Olefin & BTX & Ethylene & Propylene & \\
\hline \multirow[t]{6}{*}{90} & 0.5 & $n$-hexane & 82 & 59 & 2 & 15 & 28 & [52] \\
\hline & & $\mathrm{CH}$ a & 90 & 63 & 25 & 19 & 35 & \\
\hline & & $\mathrm{MCH}^{\mathrm{b}}$ & 90 & 59 & 29 & 15 & 33 & \\
\hline & 4.5 & $n$-hexane & 82 & 59 & 2 & 15 & 28 & \\
\hline & & $\mathrm{CH}$ & 85 & 63 & 25 & 15 & 36 & \\
\hline & & $\mathrm{MCH}$ & 80 & 52 & 31 & 10 & 28 & \\
\hline \multirow[t]{6}{*}{2300} & 0.5 & $n$-hexane & 85 & 53 & 10 & 18 & 25 & \\
\hline & & $\mathrm{CH}$ & 73 & 55 & 33 & 16 & 22 & \\
\hline & & $\mathrm{MCH}$ & 59 & 50 & 39 & 10 & 16 & \\
\hline & 4.5 & $n$-hexane & 79 & 53 & 10 & 13 & 25 & \\
\hline & & $\mathrm{CH}$ & 30 & 63 & 25 & 3 & 14 & \\
\hline & & $\mathrm{MCH}$ & 16 & 47 & 25 & 1 & 3 & \\
\hline \multirow[t]{2}{*}{100} & 0.33 & Model naphtha & & 57 & 22 & $39 c$ & $53^{c}$ & [45] \\
\hline & 4.33 & & & 54 & 23 & $35^{c}$ & $54^{c}$ & \\
\hline \multirow[t]{2}{*}{2000} & 0.33 & & & 40 & 37 & $52^{c}$ & $44^{c}$ & \\
\hline & 4.33 & & & 39 & 25 & $33^{c}$ & $54^{c}$ & \\
\hline \multirow[t]{4}{*}{100} & 0.33 & $n$-hexane & 92 & & & & & \\
\hline & & $\mathrm{MCH}$ & 100 & & & & & \\
\hline & 4.33 & $n$-hexane & 90 & & & & & \\
\hline & & $\mathrm{MCH}$ & 100 & & & & & \\
\hline \multirow[t]{4}{*}{2000} & 0.33 & hexane & 95 & & & & & \\
\hline & & $\mathrm{MCH}$ & 100 & & & & & \\
\hline & 4.33 & $n$-hexane & 72 & & & & & \\
\hline & & $\mathrm{MCH}$ & 67 & & & & & \\
\hline \multirow[t]{2}{*}{150} & 2.33 & $n$-hexane & 94 & 36 & 15 & & & [59] \\
\hline & 18 & & 92 & 37 & 13 & & & \\
\hline \multirow[t]{2}{*}{1500} & 2.33 & & 96 & 23 & 35 & & & \\
\hline & 18 & & 87 & 28 & 24 & & & \\
\hline 100 & 15 & $n$-hexane & 90 & 50 & & & & [51] \\
\hline 500 & 15 & & 72 & 12 & & & & \\
\hline 2000 & 15 & & 60 & 12 & & & & \\
\hline \multirow[t]{2}{*}{106} & 0 & hexane & 80 & & & & & [18] \\
\hline & 15 & & 48 & & & & & \\
\hline \multirow[t]{2}{*}{380} & 0 & & 80 & & & & & \\
\hline & 15 & & 40 & & & & & \\
\hline \multirow[t]{2}{*}{935} & 0 & & 80 & & & & & \\
\hline & 15 & & 28 & & & & & \\
\hline \multirow[t]{3}{*}{90} & 0.5 & $n$-hexane & 94.1 & & & & & [44] \\
\hline & 7 & & 93.5 & & & & & \\
\hline & 50 & & 82 & & & & & \\
\hline \multirow[t]{3}{*}{150} & 0.33 & & 92.2 & & & & & \\
\hline & 7.5 & & 93.1 & & & & & \\
\hline & 50 & & 81 & & & & & \\
\hline \multirow[t]{3}{*}{2300} & 0.33 & & 94.7 & & & & & \\
\hline & 8.5 & & 81 & & & & & \\
\hline & 50 & & 48.3 & & & & & \\
\hline
\end{tabular}



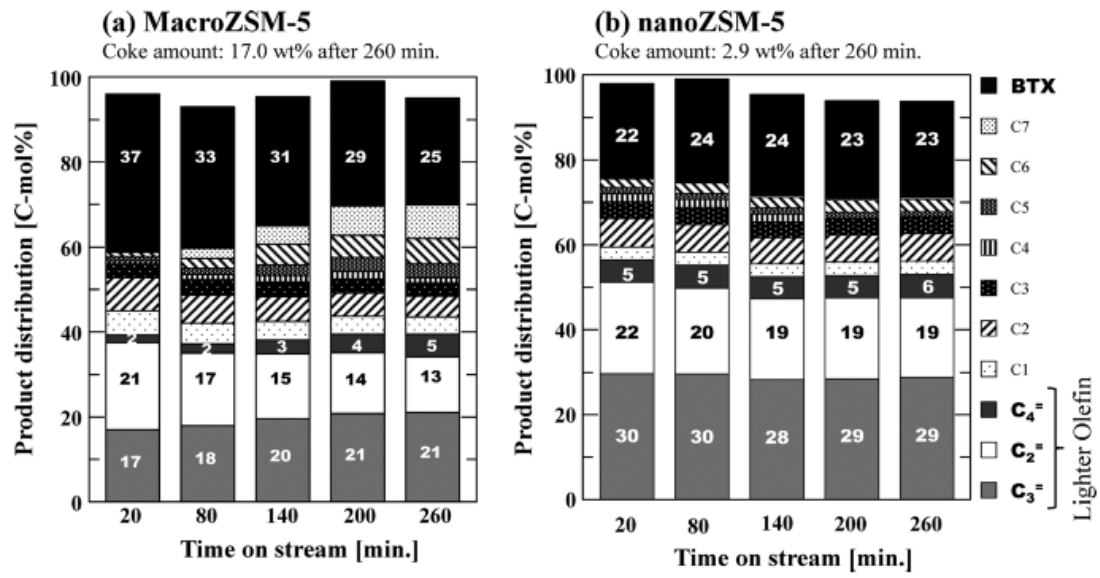

Fig. 4. Product distribution of the catalytic cracking of model naphtha over micro ZSM-5 (a) and nano ZSM-5 (b) [45].

while the changes in olefin yields on nano ZSM-5 was negligible. Unlike in $n$-hexane cracking, BTX is a main product of cyclohexane and methyl-cyclohexane cracking which leads to formation of coke [52]. The formed coke plugs the ZSM-5 pores, which not only inhibits the accessibility to catalyst active sites but also leads to excessive reaction of olefins by imposing a longer residence time.

In another research work, Konno et al. [45] compared the selectivity of nano and micro-sized ZSM-5 for a model naphtha cracking. In this research, two different sized ZSM-5 samples with the crystal size of 100 and $2000 \mathrm{~nm}$ were prepared and used in model naphtha cracking. Fig. 4 and Table 2 show the product distribution and selectivity for both samples. Micro ZSM-5 has a lower yield for olefins compared to nano ZSM-5. Also, it is evident that the ethylene distribution was reduced with reaction time from $21 \%$ to $13 \%$ when micro ZSM-5 was used, while this amount was almost same with reaction time for nano ZSM-5 (from $22 \%$ to $19 \%$ ). In multi-component diffusion systems, like naphtha cracking, hydrocarbon molecules with a lower diffusivity such as naphthenes impose a limitation on molecules with a larger diffusivity such as linear alkanes and olefins. This leads to a barrier for the generated olefins to diffuse out of the zeolite pores and subsequently a longer residence time, which resulted in production of BTX and coke inside the micropores.

A similiar result of the instability of the olefin yield on micro ZSM-5 was observed by Tago et al. [59]. Samples of ZSM-5 zeolite with sizes of 150 and $1500 \mathrm{~nm}$ are applied in $n$-hexane cracking as a model for naphtha cracking using a fixed bed reactor. The results are summarized in Table 2 . Similar to the previous studies, the low diffusion resistance of nano size ZSM-5 resulted in the rapid diffusion of light olefins out of the zeolite pores which led to higher olefin yield and lower yield of BTX compared to the micro-sized sample.

The acid sites on the external surface can have an impact on olefin yield too. This issue was observed by Rownaghi et al. [51]. Three samples with different sizes were prepared and used in $n$-hexane cracking. The size and $\mathrm{Al} /(\mathrm{Al}+\mathrm{Si})$ ratio (an indicator for acid sites) of these samples are shown in Table 3. Figs. 5 and 6 show the correlation between the light olefin yield and the two factors of crystal size and external surface acid sites/inter crystalline acid sites ratio (EAS/IAS), respectively. As expected, the smaller crystals showed a higher olefin yield because of the higher external surface that provided more pore openings and enhanced the reactions occurring inside the crystal pores. Fig. 6 also indicates that a higher EAS/IAS ratio led to a lower light olefin yield. This observation suggested that the reactions on external acid sites was different from the reactions that take place inside the pores, so less or even no acid site on the external surface can result in the conversion of all

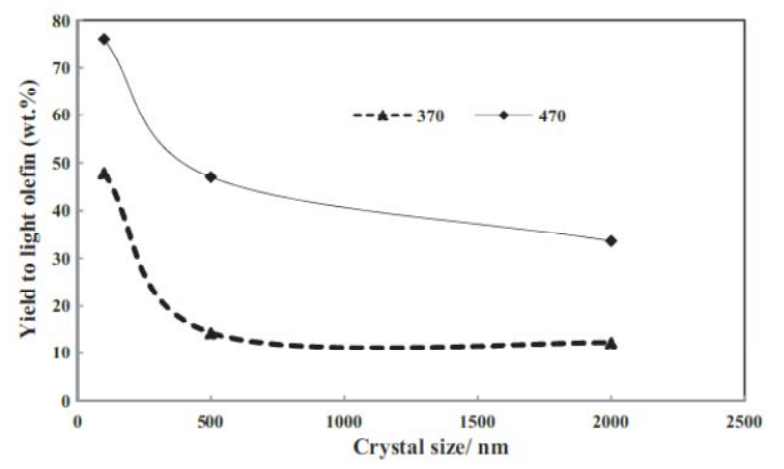

Fig. 5. Correlation between crystal size and light olefin yield at different temperatures [51].

Table 3

Physicochemical properties of the samples of Rownaghi et al. [51].

\begin{tabular}{|c|c|c|c|c|c|}
\hline \multirow{2}{*}{ Sample } & \multirow{2}{*}{$\begin{array}{c}\text { Average crystal size } \\
\text { (nm) }\end{array}$} & \multirow{2}{*}{$\begin{array}{c}\text { External surface area } \\
\left(\mathrm{m}^{2} / \mathrm{g}\right)\end{array}$} & \multicolumn{2}{|c|}{$\mathrm{Al} /(\mathrm{Si}+\mathrm{Al})(\mathrm{mol} \%)$} & \multirow{2}{*}{ EAS/IAS ratio } \\
\hline & & & In crystal (IAS) & On surface (EAS) & \\
\hline H-ZSM-5 (S) & 100 & 143 & 3.48 & 3.58 & 1.03 \\
\hline H-ZSM-5 (M) & 500 & 104 & 3.45 & 3.76 & 1.09 \\
\hline H-ZSM-5 (L) & 2000 & 75 & 3.29 & 4.01 & 1.22 \\
\hline
\end{tabular}




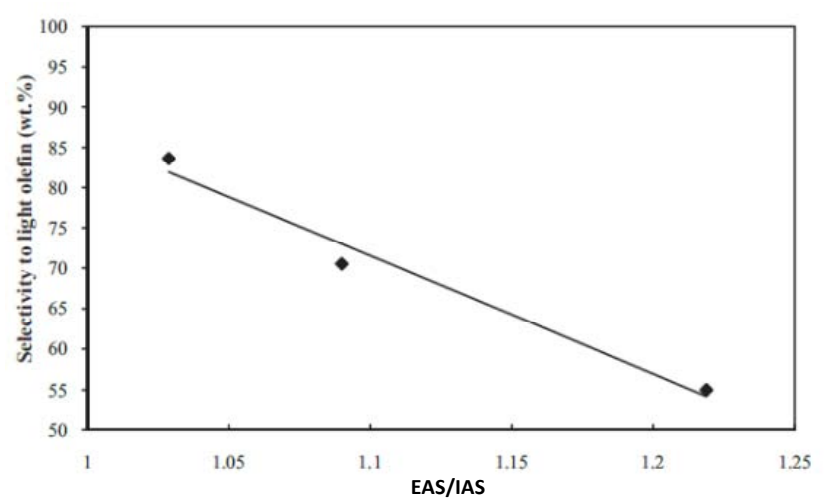

Fig. 6. Correlation between light olefin selectivity and external acid sites/inter crystalline acid sites ratio (EAS/IAS) [51].

n-hexane to light olefins [51].

\subsection{Conversion and lifetime}

Catalytic conversion and lifetime can be improved by decreasing the crystal size. In fact, the reduction of ZSM-5 crystal size resulted in the increase of external surface and available pore mouths and also reduced diffusion resistance. All these phenomena improve the accessibility to catalyst active sites which enhances the conversion. Moreover, there are many more pore openings available in nano ZSM-5 that avoid plugging of the zeolite channels due to coking, so the lifetime of catalyst increased.

Konno et al. [52] discussed earlier, the conversion with different size samples was studied. As can be seen in Fig. 1, at the beginning of the reaction, both of the micro and nano size zeolites showed the same conversion of about $83 \%$. However, the conversion with micro ZSM-5 decreased with reaction time, while the conversion with nano ZSM-5 did not change with time. The other issue is that by the reduction of crystal size to the nano scale, more external surface, and consequently more pore mouths are available which led to a longer lifetime. By changing the feedstock to cyclohexane and methylcyclohexane, the effect of the diffusion resistance on the conversion and deactivation of micro ZSM-5 became much more evident. As can be seen in Figs. 2 and 3, the conversion started to decrease considerably with the time of reaction. This was attributed to the higher diffusion resistance of cyclohexane and methyl-cyclohexane as feed and also the production of BTX which resulted in more coke deposition. When cyclohexane or methylcyclohexane was used as feed, in addition to the cracking reaction, dehydrogenation also takes place (cyclohexane to benzene and methylcyclohexane to toluene) [44,60-62]. Moreover, the high diffusion resistance of these reactants led to more coke formation on the external surface of the micro zeolite, while the high availability of external surface and pore openings in nano ZSM-5 reduced the coking problem considerably. These factors led to the rapid deactivation of micro ZSM-5 compared to nano ZSM-5. Also a comparative view of the micro and nano zeolite conversions can be observed inTable 2.

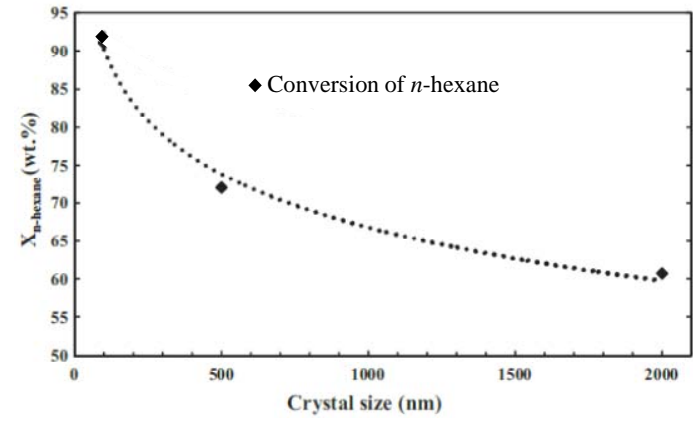

Fig. 7. Effect of crystal size on $n$-hexane conversion [51].

Similiar results on high catalytic conversion and lifetime of nano samples were obtained by Tago et al. [59] and Rownaghi et al. [51] discussed in the previous section. The results of these two experiments are summarized in Table 2 and Fig. 7. In both experiments, ZSM-5 with a smaller size showed higher and more stable conversion due to the reasons explained earlier.

In another research work, Javaid et al. [63] prepared different ZSM-5 samples with various $\mathrm{Si} / \mathrm{Al}$ ratios, crystal size and post synthesis modification. The exact sizes of the samples were not reported, but instead a comparative view between crystal size of the sample from their adsorption rate of 2,3-DMB was indicated [64]. To investigate the effect of crystal size on coke formation, which subsequently led to catalyst deactivation, an approximate plot of coke/BTX ratio against crystal size is shown in Fig. 8. It is evident that by increasing crystal size, more BTX was converted to coke which plugs the ZSM-5 pore mouth.

Mochizuki et al. [18] obtained similar results. To modify the sample crystal size, the water amount in the synthesis gel was altered. This method was also reported to have an impact on crystal size by other researchers [35,65-67]. The properties of the samples are listed in Table 4 . These samples were examined for the catalytic cracking of hexane. The relationship be-

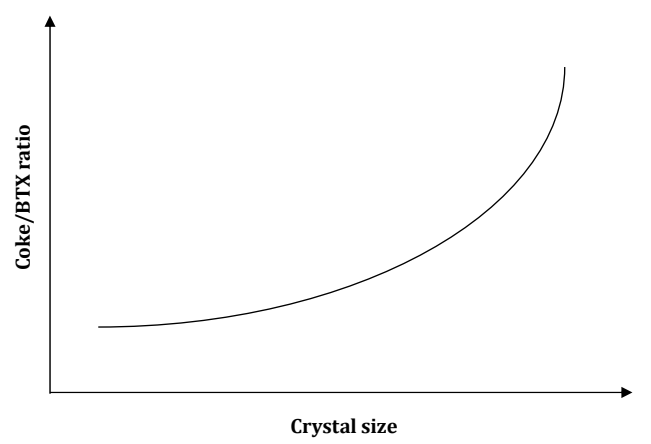

Fig. 8. Effect of crystal size on coke/BTX ratio [63].

Table 4

Crystal size, micropore volume and external surface area of the samples of Mochizuki et al. [18].

\begin{tabular}{lccc}
\hline Sample & $\begin{array}{c}\text { Crystal size } \\
(\mathrm{nm})\end{array}$ & $\begin{array}{c}V_{\mathrm{m}} \\
\left(\mathrm{cm}^{3} / \mathrm{g}\right)\end{array}$ & $\begin{array}{c}\text { External surface } \\
\text { area }\left(\mathrm{m}^{2} / \mathrm{g}\right)\end{array}$ \\
\hline H-ZSM-5 (L) & 935 & 0.16 & 12 \\
H-ZSM-5 (M) & 380 & 0.18 & 32 \\
H-ZSM-5 (S) & 106 & 0.17 & 49 \\
\hline
\end{tabular}

$V_{\mathrm{m}}$ : Micropore volume. 
tween coke amount, reaction time and conversion are shown in Fig. 9 and Table 2. It was observed that as the reaction proceeded, more coke was formed on the catalyst with a larger size and as expected, the catalyst with a larger coke amount showed a sharper decrease in conversion compared to the smaller ones.

Konno et al. [45] also compared the conversion of nano and micro-sized ZSM-5 for a model naphtha (mainly paraffins and naphthenes) cracking. Fig. 10 and Table 2 show the conversion for both these samples. It is evident that micro ZSM-5 conversion decreased rapidly with reaction time while nano ZSM-5 showed stable conversion versus time on stream. The reason for the difference in the conversion and catalyst activity was related to the limiting condition of the ZSM-5 sample, whether it is reaction limiting condition or diffusion limiting. The cracking of model naphtha takes place in the transition or diffusion limiting condition on the micro-sized sample. The reaction mainly takes place on the external surface acid sites and both reactant and products adsorb and diffuse to the zeolite pores. As previously discussed, a low diffusivity of components such as naphthenes in this system inhibits the diffusion of molecules such as olefins, which subsequently results in excessive reaction and the production of BTX and coke. In contrast, cracking of naphtha takes place on acid sites present both on external surface and within the pores when nano ZSM-5 was applied, which led to a higher conversion. Also the low diffusion resistance resulted in a smaller coke amount and longer lifetime.

Another investigation of Konno et al. [44] also explained the higher conversion and longer lifetime of nano ZSM-5 from the viewpoint of the limiting condition of the reaction. Three different sized ZSM-5 samples (2300 nm (MFI(L)), $150 \mathrm{~nm}$ (MFI(M)) and $90 \mathrm{~nm}$ (MFI(S))) were applied in $n$-hexane cracking using a fixed bed reactor. The data for the conversion over these three catalysts are listed in Table 2 . The results for this experiment showed high conversion for all three samples at the beginning of the reaction, approximately $94 \%$. However, after $50 \mathrm{~h}$ on stream, the MFI(L) conversion fell to about 48\%, while the conversion for MFI(M) and MFI(S) remain almost unchanged at $81 \%$ and $82 \%$, respectively. The coke amount percentage on the samples after $50 \mathrm{~h}$ were $59.6 \%, 21.0 \%$ and $7.5 \%$ for MFI(S), MFI(M) and MFI(L), respectively. As observed, although much more amount of coke was produced on MFI(S) and MFI(M) compared to MFI(L), they showed higher and more stable conversion. As discussed earlier, in the micro-sized sample, cracking takes place in the diffusion limiting condition. By coke deposition on the external surface of the micro ZSM-5 sample, the active sites for $n$-hexane cracking are plugged and the catalyst lifetime and conversion decrease significantly.

\section{Effect of reaction parameters on nano ZSM-5 performance}

\subsection{Reaction temperature}

Reaction temperature is an important factor for altering the
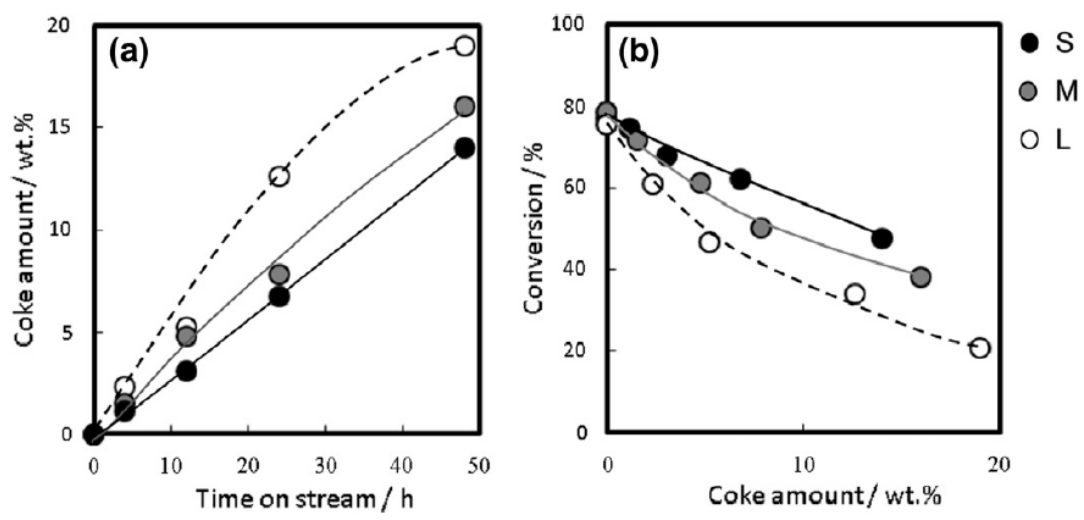

Fig. 9. Relationship between reaction time, coke amount and conversion for three different sized samples [18].

(a) MacroZSM-5

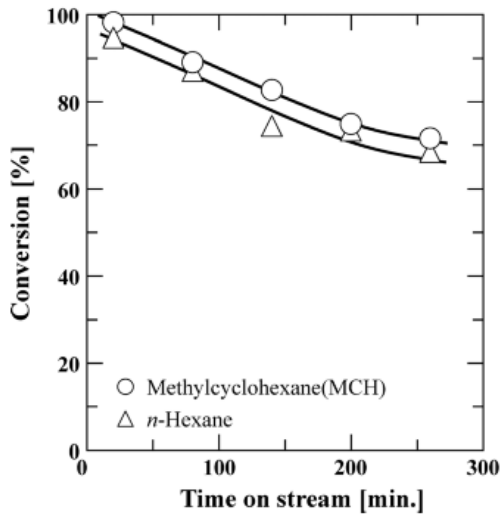

(b) nanoZSM-5

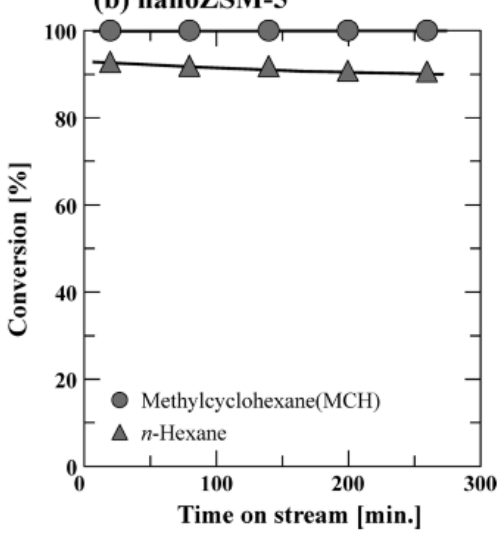

Fig. 10. Conversion of $n$-hexane and methylcyclohexane in the cracking of model naphtha over micro ZSM-5 (a) and nano ZSM-5 (b) [45]. 
product selectivity and conversion in naphtha cracking on nano ZSM-5. In fact, the reaction temperature can change and control the reaction routes that take place in naphtha cracking.

Konno et al. [52] investigated the application of nano ZSM-5 at the three temperatures of 500,600 , and $650{ }^{\circ} \mathrm{C}$. The results are shown in Fig. 11. As can be seen, by increasing the temperature, light olefins and BTX selectivity increased while paraffin selectivity decreased. This observation was attributed to the rapid dehydrogenation (e.g., paraffin to olefin) at high temperatures.

Similiar results were also observed by Rownaghi et al. [51]. Nano ZSM-5 was applied in $n$-hexane cracking at the two temperatures of 370 and $470{ }^{\circ} \mathrm{C}$. The results for the selectivity and conversion are shown in Table 5. Similar to above discussed results, the light olefin yield increased with temperature (from 47.9 to $76.1 \mathrm{wt} \%$ ).

However, increasing of the selectivity to propene and butenes with rising temperature does not always take place and depends on inhibiting the excessive reaction of these alkenes to BTX by controlling catalyst acidity. This issue was studied by Mochizuki et al. [18]. The effect of temperature on the catalytic performance in the temperature range of 450 to $650{ }^{\circ} \mathrm{C}$ was examined. It was observed that although the selectivity to propene and butenes was high at $450{ }^{\circ} \mathrm{C}$, as the temperature increased, the selectivity decreased and BTX yield rose due to the transformation of propene and butenes to aromatics with an increase in temperature. Moreover, with increasing temperature, ethene selectivity also increased since it is formed via the energetically unfavorable primary carbenium ions, in both the unimolecularand bimolecular mechanisms $[13,28]$, which needs a high activation energy.

\subsection{Feedstock}

Naphtha consists of different hydrocarbons such as linear alkanes, naphthenes, iso-paraffins, olefins and aromatics $[3,4]$. Each of these constituents exertits effect on the cracking reac-
Table 5

$n$-Hexane conversion, light olefin yield and selectivity of nano ZSM-5 at different reaction temperatures [51].

\begin{tabular}{lcccll}
\hline Reaction & \multirow{2}{*}{$\begin{array}{c}n \text {-Hexane } \\
\text { temperature }\left({ }^{\circ} \mathrm{C}\right)\end{array}$} & $\begin{array}{c}\text { Light olefin } \\
\text { conversion }(\%)\end{array}$ & \multicolumn{3}{c}{ Selectivity (wt\%) } \\
\cline { 4 - 6 } & 68 & 47.9 & 22.5 & 32.0 & 16 \\
\hline 370 & 91 & 76.1 & 27.0 & 37.7 & 18.9 \\
\hline 70 & & & & &
\end{tabular}

tion. In fact, hydrocarbons such as naphthenes have a higher diffusion resistance which affects the selectivity and conversion. Also, aromatic compounds, such as BTX, are the main product in the cracking of certain naphthenes.

Konno et al. [52] investigated the effect of three different feedstocks, i.e. $n$-hexane, cyclohexane (CH) and methyl-cyclohexane $(\mathrm{MCH})$, as naphtha representative hydrocarbons on the catalytic performance of nano ZSM-5. Comparing Figs. 1(b), 2(b) and 3(b) shows two minor differences in the nano ZSM-5 catalytic performance when $\mathrm{CH}$ and $\mathrm{MCH}$ were used as feedstock compared to $n$-hexane: (1) A slight decrease in catalyst conversion with reaction time, and (2) Higher selectivity for BTX. These observations were attributed to BTX production during naphthene cracking which led to coke formation. The coke amount and percentage of available pore volume after different reaction times for nano ZSM-5 are shown in Table 6. Comparing the data in Table 6 and Table 1 shows that the pore volume remained constant in $n$-hexane cracking while it decreased for $\mathrm{CH}$ and $\mathrm{MCH}$ cracking after 4.5 $\mathrm{h}$, and this reduction in micropore volume is the result of by different deactivation mechanisms. In $n$-hexane cracking, although the coke amount increased to $13.7 \%$ after $15 \mathrm{~h}$, the pore volume was almost unchanged. This observation suggested that the coke formation only occurred on the external surface of the zeolite and the acid sites within the pores remained without coke. In contrast, in naphthene cracking, the pore volume was reduced after $15 \mathrm{~h}$ as the amount of coke increased. This was attributed to the formation of BTX as the
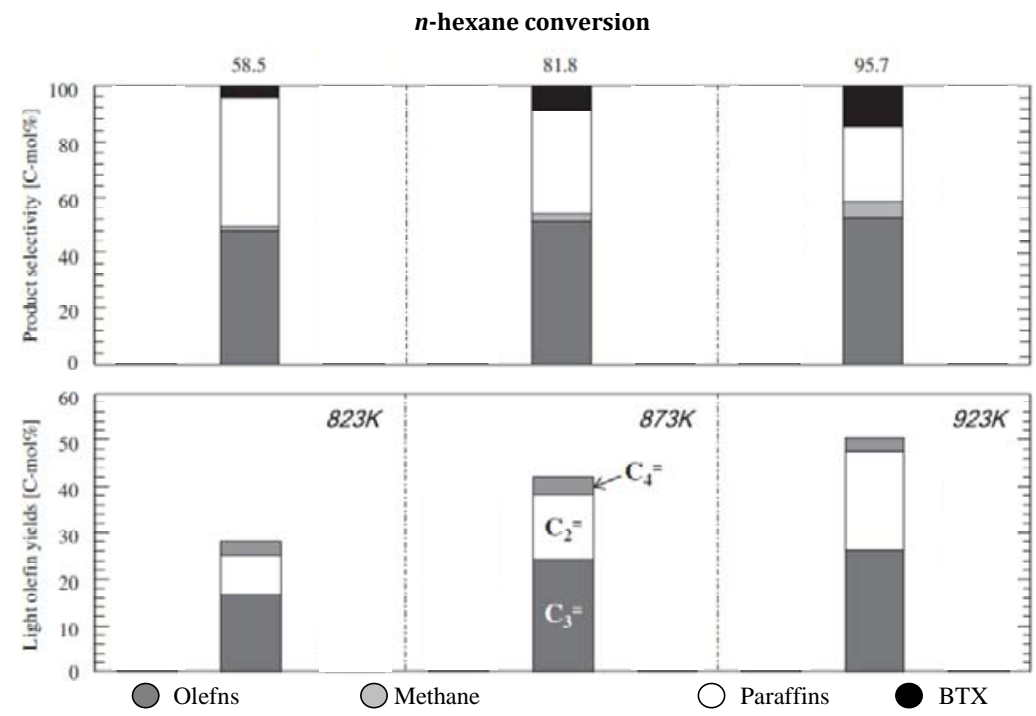

Fig. 11. Product selectivity, light olefin yield and $n$-hexane conversion for nano ZSM- 5 sample at three different temperatures [52]. 
Table 6

Coke amounts and micropore volume after cracking of different feeds over nano ZSM-5 for various reaction times [52].

\begin{tabular}{lccc}
\hline Feed & $\begin{array}{c}\text { Reaction time } \\
(\mathrm{h})\end{array}$ & $\begin{array}{c}\text { Coke amount } \\
(\%)\end{array}$ & $\begin{array}{c}V_{\mathrm{m}} \\
\left(\mathrm{cm}^{3} / \mathrm{g}\right)\end{array}$ \\
\hline$n$-Hexane & 4.5 & 1.5 & 0.18 \\
& 10 & 4.4 & 0.17 \\
Cyclohexane & 15 & 13.7 & 0.17 \\
Methyl-cyclohexane & 4.5 & 2.8 & 0.17 \\
& 4.5 & 5.1 & 0.16 \\
& 10 & 10 & 0.15 \\
\hline
\end{tabular}

$V_{\mathrm{m}}$ : Micropore volume.

main product of methyl-cyclohexane dehydrogenation in the crystal micropores [61,62]. The formed BTX was adsorbed by the acid sites inside the crystal, and transformed to coke which plugged the pores. Therefore, coking occurred on both the external surface and within the crystal when naphthenes were used as feedstock, which resulted in a higher deactivation rate.

\section{Conclusions}

The effect of ZSM-5 crystal size reduction on naphtha catalytic cracking was investigated. Catalytic cracking is a good substitute for thermal cracking, which is the most energy consuming process in the petrochemical industry. In term of economy, catalytic cracking can reduce the costs by giving a high propene/ethane ratio at relatively lower temperatures. Many researches indicated that nano size ZSM-5 exhibited more stable selectivity to light olefins. By the application of a nano ZSM-5 zeolite, the catalyst life time and conversion were increased considerably. These results were attributed to the lower diffusion resistance and more external surface in nano ZSM-5. The effects of the reaction parameters of temperature and feedstock on nano ZSM-5 performance were discussed. A high temperature favored BTX and light olefin selectivity. However, the selectivity to propylene and butylenes also depended on controlling the further reaction of these alkenes to BTX. It was also explained that naphthenes as feedstock resulted in more BTX production and instability in catalyst conversion compared to linear alkanes such as $n$-hexane. This was due to the different mechanisms of coking which deactivated the acid sites available on both the external surface and within the crystal pores.

\section{Suggestion for further investigations}

Recently, efforts were made to prepare nanosheet ZSM-5 with one dimension as small as the size of a few or even a unit cell. These catalysts are very promising due to the reduced diffusion path length, enhanced catalytic activity and lifetime [68]. The application of these materials in catalytic cracking can improve different parameters of the process but it still needs more investigation since there are not many researches in this field.

It is also important to note that although nano zeolites showed promising results in many reactions, such as naphtha cracking as observed in this paper, however, their practical application is still limited. The main issues are: (1) Most of the synthesis methods are still on the laboratory scale and in the investigation phase; (2) High cost of scaling up the production of these materials; (3) Design of equipment to be compatible with the nano materials; (4) resistance of industry to changes to their current methods and equipment. Considering the improving impact of nano zeolites on the various processes parameters, it is worthwhile to investigate the production and application of these materials on a larger scale than the laboratory.

\section{References}

[1] O. Bortnovsky, P. Sazama, B. Wichterlova, Appl. Catal. A, 2005, 287, 203-213.

[2] C. S. Mei, P. Y. Wen, Z. C. Liu, H. X. Liu, Y. D. Wang, W. M. Yang, Z. K. Xie, W. M. Hua, Z. Gao, J. Catal., 2008, 258, 243-249.

[3] J. L. Wan, Y. X. Wei, Z. M. Liu, B. Li, Y. Qi, M. Z. Li, P. Xie, S. H. Meng, Y. L. He, F. X. Chang, Catal. Lett., 2008, 124, 150-156.

[4] M. A. Bari Siddiqui, A. M. Aitani, M. R. Saeed, S. Al-Khattaf, Top. Catal., 2010, 53, 1387-1393.

[5] J. S. Jung, J. W. Park, G. Seo, Appl. Catal. A, 2005, 288, 149-157.

[6] T. Komatsu, H. Ishihara, Y. Fukui, T. Yashima, Appl. Catal. A, 2001, 214, 103-109.

[7] J. S. Plotkin, Catal. Today, 2005, 106, 10-14.

[8] Y. Yoshimura, N. Kijima, T. Hayakawa, K. Murata, K. Suzuki, F. Mizukami, K. Matano, T. Konishi, T. Oikawa, M. Saito, T. Shiojima, K. Shiozawa, K. Wakui, G. Sawada, K. Sato, S. Matsuo, N. Yamaoka, Catal. Surv. Jpn., 2000, 4, 157-167.

[9] D. Liu, W. C. Choi, N. Y. Kang, Y. J. Lee, H. S. Park, C. H. Shin, Y. K. Park, Catal. Today, 2014, 226, 52-66.

[10] T. Ren, M. Patel, K. Blok, Energy, 2006, 31, 425-451.

[11] Y. Wei, Z. Liu, G. Wang, Y. Qi, L. Xu, P. Xie, Y. He, Stud. Surf. Sci. Catal., 2005, 158, 1223-1230.

[12] Y. Wei, F. Chang, Y. He, S. Meng, Y. Yang, Y. Qi, Z. Liu, Recent Prog. Mesostruct. Mater., 2007, 539-542.

[13] S. Y. Han, C. W. Lee, J. R. Kim, N. S. Han, W. C. Choi, C. H. Shin, Y. K. Park, Stud. Surf. Sci. Catal., 2004, 153, 157-160.

[14] H. Krannila, W. O. Haag, B. C. Gates, J. Catal., 1992, 135, 115-124.

[15] S. M. Babitz, B. A. Williams, J. T. Miller, R. Q. Snurr, W. O. Haag, H. H. Kung, Appl. Catal. A, 1999, 179, 71-86.

[16] A. Corma, A. V. Orchillès, Microporous Mesoporous Mater., 2000, $35,21-30$.

[17] N. Katada, Y. Kageyama, K. Takahara, T. Kanai, H. A. Begum, M. Niwa, J. Mol. Catal. A, 2004, 211, 119-130.

[18] H. Mochizuki, T. Yokoi, H. Imai, R. Watanabe, S. Namba, J. N. Kondo, T. Tatsumi, Microporous Mesoporous Mater, 2011, 145, 165-171.

[19] W. O. Haag, R. M. Lago, P. B. Weisz, Faraday Discuss. Chem. Soc., 1981, 72, 317-330.

[20] G. Wang, C. M. Xu, S. S. Gao, Fuel Process. Technol., 2008, 89, 864-873.

[21] N. Rane, M. Kersbulck, R. A. van Santen, E. J. M. Hensen, Microporous Mesoporous Mater., 2008, 110, 279-291.

[22] M. A. den Hollander, M. Wissink, M. Makkee, J. A. Moulijn, Appl. Catal. A, 2002, 223, 85-102.

[23] J. Biswas, I. E. Maxwell, Appl. Catal., 1990, 63, 197-258.

[24] G. Y. Jiang, L. Zhang, Z. Zhao, X. Y. Zhou, A. J. Duan, C. M. Xu, J. S. Gao, Appl. Catal. A, 2008, 340, 176-182.

[25] X. H. Meng, J. S. Gao, L. Li, C. M. Xu, Petrol. Sci. Technol., 2004, 22, $1327-1341$. 


\section{Graphical Abstract}

Chin. J. Catal., 2016, 37: 671-680 doi: 10.1016/S1872-2067(15)61091-9

\section{Recent advances in naphtha catalytic cracking by nano ZSM-5: A review}

Shayan Miar Alipour*

Amirkabir University of Technology (Tehran Polytechnic), Iran; University of New South Wales, Australia
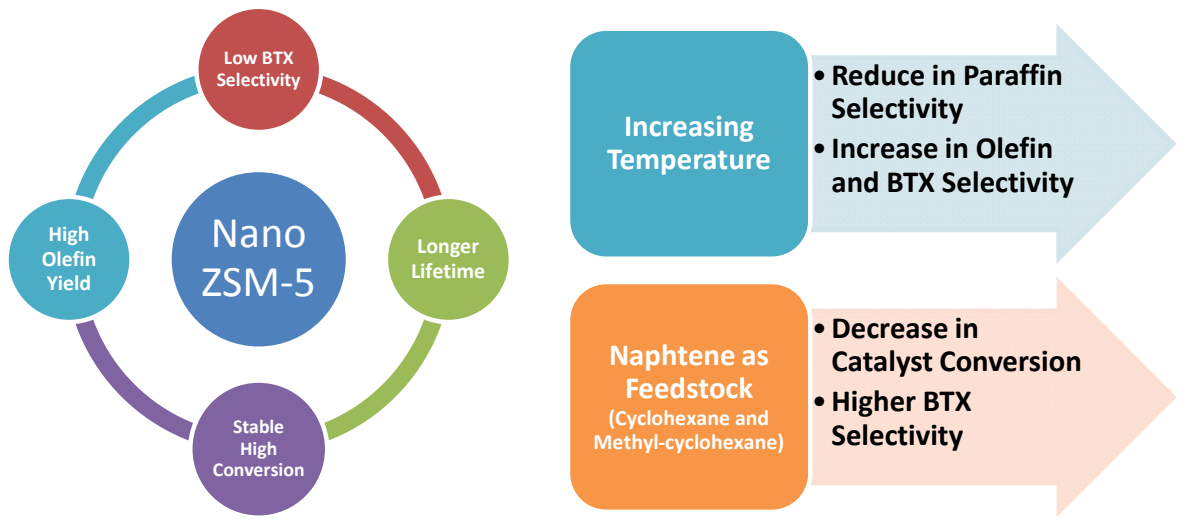

Application of nano ZSM-5 in naphtha catalytic cracking results in better conversion, longer lifetime and higher selectivity for olefins compare to micro ZSM-5. It is also indicated that altering reaction temperature and feedstock can change the conversion and the selectivity of catalyst.

[26] W. O. Haag, R. M. Lago, Proceedings of the 8th International Congress on Catalysis, Berlin, 1984, 2.

[27] J. S. Buchanan, J. G. Santiesteban, W. O. Haag, J. Catal., 1996, 158, 279-287.

[28] W. O. Haag, R. M. Dessau, R. M. Lago, Stud. Surf. Sci. Catal., 1991, 60, 255-265.

[29] S. Kotrel, M. P. Rosynek, J. H. Lunsford, J. Catal., 2000, 191, 55-61.

[30] A. Corma, J. Mengual, P. J. Miguel, Appl. Catal. A, 2012, 417-418, 220-235.

[31] M. Guisnet, P. Magnoux, Appl. Catal., 1989, 54, 1-27.

[32] K. Wakui, K. Satoh, G. Sawada, K. Shiozawa, K. Matano, K. Suzuki, T. Hayakawa, Y. Yoshimura, K. Murata, F. Mizukami, Catal. Lett., 2002, 84, 259-264.

[33] A. F. H. Wielers, M. Waarkamp, M. F. M. Post, J. Catal., 1991, 127, 51-66.

[34] S. Jolly, J. Jaussey, M. M. Bettahar, J. C. Lavalley, E. Benazzi, Appl. Catal. A, 1997, 156, 71-96.

[35] G. D. Stefanidis, A. N. Munoz, G. S. J. Sturm, A. Stankiewicz, Rev. Chem. Eng., 2014, 30, 233-259.

[36] E. G. Derouane, S. Determmerie, Z. Gabelica, N. Blom, Appl. Catal., 1981, 1, 201-224.

[37] T. Inui, G. Takeuchi, Y. Takegnami, Appl. Catal., 1982, 4, 211-221.

[38] C. Naccache, Y. B. Tarrit, in: F. R. Ribeiro, A. E. Rodrigues, L. D. Rollman, C. Naccoche eds., Zeolite: Science and Technology, Nijhoff, The Hague, 1984.

[39] N. Kumar, L. E. Lindfors, R. Byggningsbacka, Appl. Catal. A, 1996 139, 189-199.

[40] R. Byggningsbacka, N. Kumar, L. E. Lindfors, J. Catal., 1998, 178, 611-620.

[41] U. Thubsuang, H. Ishida, S. Wongkasemjit, T. Chaisuwan, Microporous Mesoporous Mater., 2012, 156, 7-15.

[42] F. Mohammadparast, R. Halladj, S. Askari, Chem. Eng. Commun., 2014, 202, 542-556.

[43] S. MiarAlipour, R. Halladj, S. Askari, E. BagheriSereshki, J. Porous
Mater., 2016, 23, 145-155.

[44] H. Konno, T. Okamura, T. Kawahara, Y. Nakasaka, T. Tago, T. Masuda, Chem. Eng. J., 2012, 207-208, 490-496.

[45] H. Konno, R. Ohnaka, J. Nishimura, T. Tago, Y. Nakasaka, T. Masuda, Catal. Sci. Technol., 2014, 4, 4265-4273.

[46] L. Tosheva, V. P. Valtchev, Chem. Mater., 2005, 7, 2494-2513.

[47] S. C. Larsen, J. Phys. Chem. C, 2007, 111, 18464-18474.

[48] S. G. Bao, G. Z. Liu, X. W. Zhang, L. Wang, Z. T. Mi, Ind. Eng. Chem. Res., 2010, 49, 3972-3975.

[49] T. Wakihara, K. Sato, S. Inagaki, J. Tatami, K. Komeya, T. Meguro, Y. Kubota, ACS Appl. Mater. Interfaces, 2010, 2, 2715-2718.

[50] T. Tago, H. Konno, M. Sakamoto, Y. Nakasaka, T. Masuda, Appl. Catal. A, 2011, 403, 183-191.

[51] A. A. Rownaghi, F. Rezaei, J. Hedlund, Chem. Eng. J., 2012, 191, 528-533.

[52] H. Konno, T. Tago, Y. Nakasaka, R. Ohnaka, J. Nishimura, T. Masuda, Microporous Mesoporous Mater., 2013, 175, 25-33.

[53] T. Tago, M. Nishi, Y. Kouno, T. Masuda, Chem. Lett., 2004, 33, 1040-1041.

[54] T. Tago, K. Iwakai, M. Nishi, T. Masuda, J. Nanosci. Nanotechnol., 2009, 9, 612-617.

[55] T. Tago, D. Aoki, K. Iwakai, T. Masuda, Top. Catal., 2009, 52, 865-871.

[56] T. Tago, M. Sakamoto, K. Iwakai, H. Nishihara, S. R. Mukai, T. Tanaka, T. Masuda, J. Chem. Eng.Jpn., 2009, 42, S162-S167.

[57] K. Iwakai, T. Tago, H. Konno, Y. Nakasaka, T. Masuda, Microporous Mesoporous Mater., 2011, 141, 167-174.

[58] T. Tago, Y. Nakasaka, T. Masuda, J. Jpn. Pet. Inst., 2012, 55, 149-159.

[59] T. Tago, H. Konno, Y. Nakasaka, T. Masuda, Catal. Surv. Asia, 2012, $16,148-163$.

[60] H. Konno, T. Okamura, Y. Nakasaka, T. Tago, T. Masuda, J. Jpn. Pet. Inst., 2012, 55, 267-274.

[61] H. S. Cerqueira, P. C. Mihindou-Koumba, P. Magnoux, M. Guisnet, 
Ind. Eng. Chem. Res., 2001, 40, 1032-1041.

[62] A. Slagtern, I. M. Dahl, K. J. Jens, T. Myrstad, Appl. Catal. A, 2010 $375,213-221$.

[63] R. Javaid, K. Urata, S. Furukawa, T. Komatsu, Appl. Catal. A, 2015 491, 100-105.

[64] K. Urata, S. Furukawa, T. Komatsu, Appl. Catal. A, 2014, 475, 335-340.
[65] Y. Y. Hu, C. Liu, Y. H. Zhang, N. Ren, Y. Tang, Microporous Mesoporous Mater., 2009, 119, 306-314.

[66] M. Khatamian, M. Irani, J. Iran Chem. Soc., 2009, 6, 187-194.

[67] R. Van Grieken, J. L. Sotelo, J. M. Menendez, J. A. Melero. Microporous Mesoporous Mater., 2000, 39, 135-147.

[68] R. Kore, R. Srivastava, B. Satpati, Chem. Eur. J., 2014, 20, 11511-11521.

\section{纳米ZSM-5用于石脑油催化裂化的最新进展 \\ Shayan Miar Alipour ${ }^{\mathrm{a}, \mathrm{b}, *}$ \\ a阿米尔卡比尔理工大学(德黑兰理工学院)化学工程学院, 德黑兰, 伊朗 \\ b新南威尔士大学颗粒和催化研究实验室, 新南威尔士悉尼2052, 澳大利亚}

摘要: 综述了纳米ZSM-5在石脑油催化裂解中的应用. 比较了纳米ZSM-5和毫米级ZSM-5对产物选择性、反应转化率和催 化剂寿命的影响. 纳米ZSM-5的应用不仅延长了催化剂寿命, 而且表现出更稳定的轻质烯烃选择性. 讨论了反应条件, 如 温度和进料对纳米ZSM-5催化性能的影响, 发现高温和线式烷烃作为进料时可提高轻质烯烃的选择性和反应转化率.

关键词: 纳米ZSM-5; 晶粒大小; 石脑油裂解; 轻质烯烃; 反应参数

收稿日期: 2016-02-04. 接受日期: 2016-03-31. 出版日期: 2016-05-05.

*通讯联系人. 电话: +61-431287016; 传真:+61-293855966; 电子信箱: shayan_a@aut.ac.ir, s.miaralipour@student.unsw.edu.au 本文的英文电子版由Elsevier出版社在ScienceDirect上出版(http://www.sciencedirect.com/science/journal/18722067).

\section{Chinese Journal of Catalysis (《催化学报》)文种变更为英文的通知}

经国家新闻出版广电总局批准，《催化学报》于 2016 年开始业务范围中的文种变更为英文, 变更后的期刊 基本信息如下：期刊名称Chinese Journal of Catalysis (《催化学报》), 中国标准连续出版物号 ISSN 0253-9837, 国内统一连续出版物号 CN 21-1601/O6, 月刊.

今后, 本刊录用稿件全部以英文全文形式发表, 英文全文电子版在 Elsevier 出版社 ScienceDirect 网络平台 上出版. 为兼顾国内读者并保持期刊的中国特色，《催化学报》印刷版将同时刊登英文文章的扩展版中文摘要.

我们相信, 期刊文种变更为英文后将为国内外催化研究工作者提供一个更好的交流和展示平台. 《催化学 报》编委会及编辑部全体成员将通过不解努力将该刊推向一个新的高度, 使其以更好的质量、更高的学术水平 面向世界, 跻身于国际优秀学术期刊行列. 